\title{
De relatie tussen scholing en loopbaan vanuit een arbeidsmarkt-theoretische invalshoek
}

Citation for published version (APA):

Dekker, R. (1994). De relatie tussen scholing en loopbaan vanuit een arbeidsmarkt-theoretische invalshoek. Researchcentrum voor Onderwijs en Arbeidsmarkt, Faculteit der Economische Wetenschappen. ROA Working Papers No. 6 https://doi.org/10.26481/umarow.1994006

Document status and date:

Published: 01/01/1994

DOI:

10.26481/umarow.1994006

Document Version:

Publisher's PDF, also known as Version of record

\section{Please check the document version of this publication:}

- A submitted manuscript is the version of the article upon submission and before peer-review. There can be important differences between the submitted version and the official published version of record.

People interested in the research are advised to contact the author for the final version of the publication, or visit the DOI to the publisher's website.

- The final author version and the galley proof are versions of the publication after peer review.

- The final published version features the final layout of the paper including the volume, issue and page numbers.

Link to publication

\footnotetext{
General rights rights.

- You may freely distribute the URL identifying the publication in the public portal. please follow below link for the End User Agreement:

www.umlib.nl/taverne-license

Take down policy

If you believe that this document breaches copyright please contact us at:

repository@maastrichtuniversity.nl

providing details and we will investigate your claim.
}

Copyright and moral rights for the publications made accessible in the public portal are retained by the authors and/or other copyright owners and it is a condition of accessing publications that users recognise and abide by the legal requirements associated with these

- Users may download and print one copy of any publication from the public portal for the purpose of private study or research.

- You may not further distribute the material or use it for any profit-making activity or commercial gain

If the publication is distributed under the terms of Article $25 \mathrm{fa}$ of the Dutch Copyright Act, indicated by the "Taverne" license above, 
De relatie tussen scholing en loopbaan vanuit een arbeidsmarkt-theoretische invalshoek

ROA-W-1994/6

Ron Dekker

Researchcentrum voor Onderwijs en Arbeidsmarkt

Faculteit der Economische Wetenschappen

Rijksuniversiteit Limburg

Maastricht, december 1994 


\section{CIP-GEGEVENS KONINKLIJKE BIBLIOTHEEK, DEN HAAG}

Dekker, Ron

De relatie tussen scholing en loopbaan vanuit een arbeidsmarkttheoretische invalshoek / Ron Dekker. Maastricht: Researchcentrum voor Onderwijs en Arbeidsmarkt, Faculteit der Economische Wetenschappen, Rijksuniversiteit Limburg. - (Werkdocument / Researchcentrum voor Onderwijs en Arbeidsmarkt, ISSN 0922-4645; ROA-W-1994/6)

Met lit. opg.

ISBN 90-5321-151-9

Trefw.: onderwijs en loopbaanplanning. 
Inhoudsopgave

\section{Bladzijde}

1 Inleiding

1

2 De begrippen scholing en loopbaan

3 Arbeidsmarkttheorieën over de relatie scholing-carrière

4 Conclusie 9

$\begin{array}{lr}\text { Literatuur } & 10\end{array}$ 


\section{Inleiding}

Wie zal er in slagen om president-directeur van een grote multinational te worden? Is de levensloop van krantejongen tot miljonair in werkelijkheid mogelijk? ledereen droomt er van. Velen zullen een poging wagen, maar slechts enkelen zullen slagen. Immers, om topfuncties te bereiken moet doorgaans een lang opleidingen- en beroepentraject worden afgelegd en gaandeweg dit traject zijn er tal van beslismomenten die bepalend zijn voor de uiteindelijke positie op de arbeidsmarkt. In feite moeten er reeds vanaf de middelbare school keuzes gemaakt worden, die van invloed zijn op de latere beroepsuitoefening.

Het is dus van belang om enerzijds goed op de hoogte te zijn van de implicaties van de schoolkeuze op de arbeidsloopbaan en anderzijds om, eenmaal op de arbeidsmarkt, zo snel mogelijk wegwijs te worden en op een perspectiefvol carrièrepad te komen. Het is daarom belangrijk om goede informatie te hebben over de aansluiting tussen opleiding en beroep. Dat deze informatie onvoldoende aanwezig is, blijkt uit het feit dat veel arbeidsmobiliteit in het begin van de loopbaan te wijten is aan het ontbreken van goede arbeidsmarktinformatie (Olzewski, 1981). Nieuwkomers op de arbeidsmarkt vinden hun weg in de praktijk door net zo lang van baan te veranderen totdat een goede matching met een functie is bereikt. Zo blijkt uit een onderzoek van Topel and Ward (1988) dat op de Amerikaanse arbeidsmarkt twee derde van de totale baanmobiliteit in de eerste tien jaar van het arbeidsleven wordt gerealiseerd. Door goede arbeidsmarktinformatie te presenteren over met name de aansluiting tussen opleidingen en beroepen, kan de matching tussen de aanbieders van arbeid en de beschikbare functies verbeterd worden.

Onze stelling is dat de gevolgde opleiding sterk bepalend is voor de latere beroepsuitoefening. Zeker, er zijn meerdere factoren die van invloed zijn op de individuele loopbaan. Maar in plaats van een breed overzicht van de factoren die van belang zijn voor de loopbaan, kiezen we in dit paper echter voor de diepte en zullen we de relatie die er bestaat tussen scholing en loopbaan vanuit meerdere invalshoeken belichten. Hiervoor gaan we in paragraaf 2 eerst in op de kernbegrippen scholing en loopbaan. Daarna wordt in paragraaf 3 vanuit verschillende arbeidsmarkttheorieën ingegaan op de relatie tussen deze twee begrippen. Het paper eindigt in paragraaf 4 met conclusies ten aanzien van de relatie tussen scholing en carrière op basis van de in dit paper besproken economische arbeidsmarkttheorieën.

\section{De begrippen scholing en loopbaan}

\section{Scholing}

Het begrip scholing kan zeer breed worden gedefinieerd als het vergaren van kennis en vaardigheden, die nodig zijn voor de (latere) beroepsuitoefening. Is daarmee alle verworven kennis te classificeren als scholing? Strikt genomen zou men zich kunnen beperken tot de opleidingen die aan de reguliere scholen worden gedoceerd. Maar dan zou men in Nederland een groot deel van het deeltijd- en het niet-regulier onderwijs (avondopleidingen, leerlingwezen, in-service opleidingen e.d.) buiten beschouwing moeten laten. Bovendien stopt scholing niet bij het verlaten van de school of bij de intrede op de arbeidsmarkt. Bedrijfsopleidingen nemen een prominente plaats in het kwalificatietraject in als we bedenken dat de uitgaven aan bedrijfsopleidingen in Nederland in 19903 miljard bedroegen en dat door een derde van het totale aantal werknemers bedrijfsopleidingen werden gevolgd (Centraal Bestuur voor de Arbeidsvoorziening, 1993). 
In dit paper definiëren we scholing als het vergaren van kennis en vaardigheden, hetzij door middel van het volgen van (reguliere) scholing vóór arbeidsmarktintrede, hetzij door het volgen van voor het beroep relevante cursussen.

Behalve deze scholing zijn ook werkervaring en training on-the-job belangrijke componenten van de kwalificatie-ontwikkeling van werkenden. We nemen deze twee componenten niet op bij de scholing, omdat ze verbonden zijn ('embodied') aan de functie. We zullen ze in de volgende paragraaf bij het bespreken van de relatie tussen scholing en loopbaan overigens wel meenemen, maar ze zullen worden onderscheiden van de hierboven gedefinieerde scholing.

\section{Loopbaan}

Ook van het begrip carrière of loopbaan bestaan er veel definities. Het woord carrière stamt letterlijk uit de tijd van de Romeinen (Gowler en Legge, 1989): 'carraria' betekent rijbaan of weg ('road or carriageway'). Later kreeg het woord in het Frans de betekenis 'renbaan', hetgeen verrassend goed past bij de hedendaagse yuppie-interpretatie van een 'survival of the fittest'.

Maar niet alleen de maatschappelijke betekenis van het begrip carrière is ambivalent. De verschillende wetenschappelijke disciplines, die zich met onderzoek naar carrières bezig houden, hanteren eveneens elk hun eigen definitie. Sterker nog, zelfs binnen de disciplines zijn de meningen verdeeld. Een nietuitputtend overzicht binnen de sociale wetenschappen levert de volgende interpretaties op:

- 'upward mobility within the occupational hierarchy' (Olzewski, 1981; Doeringer and Piore, 1971): loopbaan als vertikale mobiliteit;

- 'an empirical regularity in the labour market' (Spilerman, 1977): loopbaan als reguliere activiteit;

- 'a life time activity to attain status and earnings' (Blau and Duncan in Bielby, 1981; Mayer and Carrol, 1987): loopbaan als status;

- 'the evolving sequence of a person's work experiences over time' (Arthur, Hall and Lawrence, 1989): loopbaan als opeenvolging van werkervaringen.

De laatste definitie sluit aan bij de doelstelling van ons onderzoek naar de relatie tussen scholing en carrière, omdat twee essentiële kenmerken van carrière worden genoemd: de interactie tussen de werknemer en de arbeidsorganisatie, alsmede de tijdsdimensie. Of zoals Arthur et al. (op. cit. p. 8) stellen: 'careers reflect the relationship between people and the providers of official position, namely institutions or organizations, and how these relationships fluctuate over time'.

Uit deze definitie blijkt dat carrières niet alleen een individueel perspectief hebben, maar dat er ook structurele aspecten bestaan. Zijn in de individuele benadering factoren als leeftijd, geslacht, opleiding en sociale achtergrond belangrijk. In de structurele visie daarentegen wordt de nadruk gelegd op organisatiefactoren, zoals het organisatietype en het soort baan. Ook de arbeidsmarktstructuur is bepalend voor het carrièreverloop. Dit vinden we ook terug in het begrip carrière-systeem, dat is gedefinieerd als 'een mogelijk pad via welk werknemers zich ontwikkelen gedurende hun werkzaamheden binnen een organisatie' (Sonnenfeld, 1989, p. 202, zie ook Hondeghem, 1990). De overeenkomst met de eerder geformuleerde 'individuele' carrièredefinitie van Arthur et al. is treffend, maar de zienswijze is ditmaal vanuit de organisatie.

Tenslotte is er een combinatievariant, waarin zowel individuele als structurele factoren een rol spelen. Sicherman (1990) noemt het zoekgedrag, het reeds gevolgde beroepentraject en exogene veranderingen op de arbeidsmarkt of in de persoonlijke omstandigheden als voorbeelden. Vaak wordt 
deze combinatievariant geoperationaliseerd door variabelen uit beide invalshoeken in één carrièremodel op te nemen (het zogenaamde additieve structuralisme, zie Brüderl, 1992). Glebbeek (1993) slaagt er echter in om deze combi-variant meer te laten zijn dan de optelling van de aparte onderdelen. In zijn selectie-perspectief wordt op theoretisch niveau aangegeven hoe de interactie tussen individuele en structurele factoren verloopt. We zullen hierop in de volgende paragraaf nog terug komen.

Alvorens we vanuit de arbeidsmarkttheorieën de relatie tussen scholing en carrière gaan beschrijven, merken we op dat in deze theorieën vaak sprake is van mobiliteit, die vervolgens wordt vereenzelvigd met carrière. In veel gevallen zal dat inderdaad ook zo zijn. Toch is mobiliteit geen noodzakelijke voorwaarde om carrière te maken. Carrière kan voor een groot deel plaatsvinden binnen de organisatie. Meestal spreken we dan van interne mobiliteit. Het blijkt dat de meeste significante loonstijgingen gepaard gaan met (interne) baanveranderingen (Prendergast, 1993). Voor een deel kunnen deze functies worden gecreëerd om werknemers binnen de organisatie te kunnen laten doorgroeien.

\section{Arbeidsmarkttheorieën over de relatie scholing-carrière}

Inleiding

Op de arbeidsmarkt vindt het proces van beloning en allocatie van banen plaats (McNabb, 1987) en in de loop der tijd zijn er tal van arbeidsmarkttheoriëen ontwikkeld met betrekking tot de loonvorming en de matching mechanismen. Met betrekking tot dit laatste noemt Hachen (1990) in zijn overzichtsartikel primaire en secundaire markten, interne arbeidsmarkten, monopolies en markten met volledige concurrentie, loon- en banenmarkten en gesloten en open arbeidsrelaties als mogelijke verklaringen om werknemers en functies aan elkaar te relateren. De begrippen carrière en mobiliteit zijn echter opmerkelijk afwezig in al deze theorieën, ondanks het feit dat veel ideeën in de arbeidsmarkttheorie betrekking hebben op baanwisselingen binnen en tussen arbeidsorganisaties (Hachen op cit, p. 326).

In deze paragraaf gaan we vanuit de economische theorie nader in op de relatie tussen scholing en carrière. We volgen de in de vorige paragraaf beschreven indeling in individuele, structurele en gecombineerde standpunten en beginnen bij de neoklassieke theorie, waarin de keuzevrijheid van het individu sterk wordt benadrukt. Vervolgens worden steeds een of meerdere veronderstellingen binnen het neoklassieke kader losgelaten en we eindigen op de bedrijfsinterne arbeidsmarkt, waar structurele factoren overheersen. Dat wil overigens niet zeggen dat we de ene theorie verwerpen ten gunste van een andere. Integendeel, het is goed mogelijk dat de verschillende arbeidsmarktstructuren naast elkaar voorkomen in de economische werkelijkheid.

\section{Neoklassieke theorie}

In de neoklassieke context maximalizeren rationele agenten hun nut op een (arbeids)markt met volledige concurrentie waarbij er geen informatiekosten zijn (Pfriem, 1979). De nutsmaximalisatie impliceert het maximaliseren van het looninkomen en de vrije tijd. De markt met volledige concurrentie betekent dat noch de individuele werknemer, noch de individuele werkgever de loonvoet kunnen bepalen of beïnvloeden. De gelijkheid tussen marginale kosten en opbrengsten bepaald dan het loon, dat daarmee ook informatief is voor de produktiviteit van de werknemer (Williamson, 1975). De volledige informatie geeft aan dat zowel vragers als aanbieders volledig op de hoogte zijn van de gebeurtenissen op de arbeidsmarkt zonder dat daar kosten aan verbonden zijn. In het traditionele neoklassieke arbeidsmarktmodel ligt de nadruk primair op het verklaren van de loonvorming in de lange-termijn 
evenwichtssituatie (De Grip, 1987) en dus minder op de allocatie van arbeid. Arbeid wordt in eerste instantie homogeen verondersteld. Het loslaten van deze homogeniteit is een eerste vereiste om de met de allocatie van arbeid samenhangende processen als mobiliteit en carrière te kunnen beschrijven.

Dat gebeurt in het midden van de jaren '50 als de human capital theorie wordt ontwikkeld (Becker, 1983). Arbeid wordt heterogeen verondersteld als gevolg van verschillen in produktieve vaardigheden tussen de individuen. Die hebben de keuze tussen meteen gaan werken, of de arbeidsmarktintrede uit te stellen en te investeren in scholing. Aan deze scholing zijn echter kosten verbonden en bovendien mist men ook de inkomsten uit arbeid. Het uitgangspunt van de human capital theorie is echter dat deze scholingsbeslissing leidt tot een hogere produktiviteit en bijgevolg een hoger loon, waarmee de gedane investeringen kunnen worden terugverdiend.

Behalve individuen kunnen ook bedrijven investeren in scholing. Anders dan de individuen, die investeren in breed toepasbare (en verkoopbare) kennis, zullen de bedrijven vooral investeren in bedrijfsspecfieke kennis. Bedrijven zullen niet bereid zijn om algemene opleidingen te financieren, omdat dan het risico aanwezig is dat zij werknemers opleiden voor andere bedrijven. De bedrijfsspecifieke trainingen worden wèl door de bedrijven betaald, omdat een werknemer deze kennis immers niet buiten de organisatie kan gebruiken.

Voor beide typen scholing geldt dat, analoog aan andere investeringsbeslissingen, de terugverdientijd een belangrijk criterium is voor de scholingsbeslissing. Vanuit het individuele perspectief geredeneerd zullen daarom vooral jongeren in scholing investeren. Voor de bedrijven is de scholing behalve een investering ook een manier om werknemers aan zich te binden. De factor arbeid kent immers behalve de variabele kosten (het loon) ook een vaste kostencomponent (Oi, zie De Grip, 1985) in de vorm van de (bedrijfs-)specifieke opleiding. Deze vaste kosten impliceren dat het bedrijf zal trachten de externe mobiliteit van werknemers die specifieke kennis hebben te voorkomen. Juist omdat de bedrijfsspecifieke scholing alleen maar rendement oplevert binnen het bedrijf, zal de desbetreffende werknemer ervoor kiezen om bij het bedrijf te blijven. De bedrijfsspecifieke kennis is immers niet toepasbaar en te gelde te maken bij andere bedrijven. Daarmee is niet gezegd dat er geen carrièremogelijkheden meer zouden zijn. Met name op interne arbeidsmarkt, waarover later meer, bestaan uitgebreide mogelijkheden om binnen de organisatie door te groeien. Bovendien krijgt de desbetreffende werknemer extra werkzekerheid. Het bedrijf heeft immers een persoonsgebonden investering gedaan, die verloren gaat als de werknemer wordt ontslagen.

Andere arbeidsmarkttheorieën gaan niet zo ver om produktieve vaardigheden toe te kennen aan de (algemene) opleidingen, maar ze benadrukken dat de opleiding dienst doet om informatie over te dragen over iemands (potentiële) produktiviteit. De werknemer kent weliswaar zijn of haar eigen produktiviteit, maar de werkgever is hiervan niet op de hoogte (Ohlsson and Nilsson, 1984). Daarmee wordt in feite de assumptie van de vrije beschikbaarheid van informatie losgelaten.

Volgens de signaleringstheorie (Spence, 1974) heeft de individuele werknemer volledige notie van zijn of haar capaciteiten en van die van anderen, zodat de (relatieve) positie op de arbeidsmarkt kan worden bepaald. De werkgevers hebben deze informatie echter niet en moeten daarom op zoek naar signalen, die een indicatie geven van de produktiviteit van de toekomstige werknemers. Hier doet opleiding haar intrede. Een voorwaarde voor signalering is namelijk dat de desbetreffende indicator positief correleert met produktiviteit, maar negatief met de benodigde inspanning om dat positieve signaal af te geven. In concreto: opleiding is positief gecorreleerd met produktiviteit, maar om meer, of een hogere opleiding te bereiken moet meer inspanning worden verricht, of is meer slimheid vereist. Bijgevolg kan een meer- 
produktieve toekomstige werknemer een signaal van zijn produktiviteit afgeven door veel scholing te volgen. De minder produktieve werknemer moet hier afhaken, omdat het volgen van scholing hem meer, of zelfs te veel moeite kost.

De screening-theorie (Stiglitz, 1975) gaat eveneens uit van slechts een relatieve betekenis van scholing, maar ziet de rol van opleiding breder dan alleen een signaalfunctie. Het schoolsysteem heeft overeenkomsten met de werking van de arbeidsmarkt en wie op school goed presteert zal naar verwachting ook op de arbeidsmarkt goed functioneren. Bovendien is het ook juist op school waar het individu zijn of haar capaciteiten leert ontdekken. Tenslotte geeft het diploma van een opleiding, onder andere via de behaalde cijfers, een goede indicatie van de (relatieve) positie van het individu binnen het schoolsysteem. Scholing geeft dus naast een indicatie van een bepaald intelligentiepeil ook informatie over het leervermogen, het vermogen om opgedragen taken te volbrengen en in welke mate de eventuele werknemer een stabiel gedragspatroon kent.

Ook de wachtrij-theorie (Thurow, 1975) benadrukt de informatieve waarde die opleiding heeft bij de selectie van nieuwe werknemers. Het is in deze theorie echter niet noodzakelijk dat de werknemer zijn of haar capaciteiten kent, maar wel weer dat de werkgever geen rechtstreekse informatie heeft over de produktiviteit van de nieuwe werknemers. De wachtrij-theorie gaat een stap verder dan de signaleringsen screeningtheorie door aan te geven dat opleiding een indicatie is van de trainingskosten die de organisatie zich moet getroosten om de nieuwe werknemer effectief in te kunnen zetten. De potentiële werknemers worden door de werkgevers in een wachtrij geplaatst, geordend naar trainbaarheid. Een nieuw facet ten opzichte van de eerder besproken theorieën is verder dat de banenmarkt wordt afgescheiden van de loonmarkt, waarmee de wachtrij-theorie op het grensvlak ligt van de neo-klassieke en de institutionele theorie.

Dat institutionele aspect blijkt ook uit het feit dat de produktiviteit in deze opvatting gekoppeld is aan de functie en niet aan het individu. Bijgevolg is ook de beloning aan de functie gerelateerd. De arbeidsmarkt wordt weliswaar geruimd, maar in een dergelijke situatie kan er echter wel sprake zijn van kwalitatieve discrepanties (De Grip, 1987), omdat de individuele potentiële produktiviteit niet overeen hoeft te komen met de produktiviteit die voor de functie vereist is.

Een noodzakelijke voorwaarde dat opleiding, behalve in de bovengenoemde theorieën, ook in de praktijk kan functioneren als een signaleringsinstrument, is dat in het onderwijssysteem standaarden worden bepaald voor de verschillende opleidingen. Daarmee wordt bedoeld dat dezelfde opleiding op verschillende scholen moet leiden tot hetzelfde eindniveau. Daarnaast moet er ook enige vorm van stratificatie van het onderwijssysteem aanwezig zijn. Dat wil zeggen dat er verschillende opleidingen of -niveaus aanwezig moeten zijn, omdat er anders geen verschillen tussen de opleidingen waarneembaar zijn (Allmendinger, 1989).

Tenslotte wordt binnen het neoklassieke kader nog de job search theorie onderscheiden (zie Van Ophem, 1989). In deze theorie wordt oorspronkelijk ingegaan op de participatiebeslissing van het individu om wel of niet werk te aanvaarden. Ook nu wordt de assumptie van volledige informatie losgelaten. Ditmaal heeft echter de werknemer geen overzicht in de arbeidsmarktprocessen. Het blijkt dat de beslissing van het individu om zich wel of niet aan te bieden op de arbeidsmarkt onder deze voorwaarden is gebaseerd op een individueel reserveringsloon. Indien er een baan wordt aangeboden onder dit loon, vindt er geen arbeidsaanbod plaats. De eerste baanaanbieding waarvan het loon boven dit individuele reserveringsloon ligt wordt geaccepteerd. Opleiding is naast andere persoonskenmerken, de hoogte van de uitkering en de werkloosheidsduur een van de verklarende variabelen in dit model. 
Voordat we overgaan naar de institutionele theorieën wordt nog de transaktiekostentheorie van Williamson (1975) besproken, omdat hierin in feite de discussie plaatsvindt of transakties via de markt, dan wel binnen een organisatie verlopen.

Volgens de transaktiekostenbenadering van Williamson (1975) nemen interne markten, ofwel organisaties, de rol van het loonmechanisme en de arbeidsmarkt over als de marktpartijen geen volledige informatie hebben met betrekking tot de vraag en het aanbod van arbeid, of als er sprake is van slechts weinig transacties. Dit laatste is van toepassing op de verschillende functies indien geldt dat er sprake is van zogenaamde 'task idiosyncracies' (baan-eigenaardigheden). Dat wil zeggen dat elke functie zijn eigen typische handelingen of kennisvereisten heeft, die ertoe leiden dat er geen uitgebreide markt is voor de desbetreffende functie. Zowel de aanbieder als de vrager van arbeid kunnen in deze situatie een beter resultaat behalen (een hoger loon, respectievelijk minder arbeidskosten) door een interne markt te creëren in plaats van bilateraal op de arbeidsmarkt te onderhandelen. Net als bij de wachtrij-theorie worden de lonen dan gekoppeld aan de functie en niet aan de werknemer. De matching tussen de produktiviteit van de individuele werknemer en de functie geschiedt vervolgens via promoties binnen de organisatie.

Dit laatste punt sluit aan bij de neo-klassieke gedachtengang dat individuele factoren het carrièreverloop bepalen. Binnen de institutionele arbeidsmarkttheorieën wordt evenwel de interne structuur van de organisatie opgevoerd om aan te tonen dat de loopbanen van de werknemers bepaald worden door deze structuur en de arbeidsmarkt. Over deze interne arbeidsmarkten en de institutionele visie op de interactie tussen loopbaan en scholing gaat het vervolg van deze paragraaf.

\section{Institutionele theorieën}

Binnen de institutionele arbeidsmarkttheorieën worden de meeste neo-klassieke assumpties met betrekking tot de werking van de arbeidsmarkt verworpen. In plaats van het loonmechanisme zijn het regels en gewoonten binnen een organisatie die de arbeidsmarktstructuur bepalen. Anders is ook dat de analyses zich richten op goede versus slechte banen, in plaats van produktieve versus minderproduktieve werkenden.

De segmentatietheorieën vinden in feite hun oorsprong in het 'non-competing groups' concept van de $19 \mathrm{e}$ eeuwse Britse econoom Cairnes (1873). In tegenstelling tot wat in de human capital theorie wordt verondersteld, wordt de segmentatie van de arbeidsmarkt niet veroorzaakt door de produktiviteitsverschillen van de werkenden, maar door de vraagzijde van de arbeidsmarkt. De Balkanisatie van de arbeidsmarkt die werd geïntroduceerd door Kerr (1954) wordt gezien als de start van de moderne segmentatietheorieën.

In eerste instantie wordt daarbij een zogenaamde 'dubbele arbeidsmarkt' verondersteld, waarbij de arbeidsmarkt wordt opgedeeld in een primair en een secundair segment (Doeringer en Piore, 1971). De duale aanpak probeert te verklaren waarom werkenden met dezelfde vaardigheden toch in verschillende segmenten van de arbeidsmarkt terecht komen (Taubman en Wachter, 1986). Op het primaire segment bevinden zich de goede aantrekkelijke banen, waarbij de allocatie plaatsvindt op basis van administratieve regels en procedures (Doeringer en Piore, 1971, pag. 1). Het secundaire segment is een open markt die wordt gereguleerd door het loonmechanisme en waarop de slechte, onstabiele banen met weinig carrièremogelijkheden zich bevinden. 
Behalve de indeling in een primair en een secundair segment zijn er binnen de segmentatietheorie talloze alternatieve indelingen geconstrueerd, omdat er geen duidelijkheid is over de criteria die moeten worden gehanteerd bij de bepaling van de segmenten (Wolfs, 1990; Glebbeek, 1993). Daardoor kenmerkt de segmentatietheorie zich door talloze, zeer uiteenlopende indelingen. Gezien de inductieve benadering van deze institutionele theorievorming is dit echter niet verwonderlijk. Toch lijkt er langzamerhand enige voorkeur te ontstaan voor een opdeling van de arbeidsmarkt in drie segmenten, waarin het primaire segment verder wordt onderverdeeld in de interne arbeidsmarkten en de vakdeelmarkten. (zie bijvoorbeeld Doeringer en Piore, 1971; Lutz en Sengenberger, 1974; Glebbeek, 1993).

Op de vakdeelmarkt bestaat er een nauwe relatie tussen het beroep en de daarvoor vereiste vakopleiding (Van Hoof en Dronkers, 1980; De Grip, 1987). De vakopleidingen fungeren op de vakdeelmarkt als een standaard van kennis en produktiviteit (Mintzberg, 1983) en maken het mogelijk om vrij gemakkelijk van werkgever te wisselen. Opleiding is derhalve een middel om mobiel te zijn tussen de verschillende bedrijven op dezelfde vakdeelmarkt. Althauser en Kalleberg (1981) spreken in dit verband ook wel van beroepsinterne arbeidsmarkten, waar -in tegenstelling tot de (bedrijfs-)interne arbeidsmarkten- de werknemers meer invloed hebben.

De meeste theorievorming binnen de institutionele literatuur concentreert zich echter op de interne arbeidsmarkt. Voor de bedrijfsspecifieke vaardigheden, die in de neo-klassieke human capital theorie ook reeds ter sprake kwamen, is een belangrijke rol weggelegd voor wat betreft het goed kunnen uitoefenen van de functie en voor de verhoging van de produktiviteit van de werknemers. Ook nu kent arbeid weer een vaste kostencomponent, waardoor de tendens ontstaat om langdurige arbeidsrelaties aan te gaan en het verloop te minimaliseren om zodoende wervings-, selectie- en trainingskosten te besparen. Een nieuwe invalshoek in de interne arbeidsmarkttheorie is echter dat de meest efficiënte manier om nieuwe werknemers deze specifieke vaardigheden aan te leren verloopt via training on-thejob, die wordt gegeven door werknemers die reeds langer in het bedrijf werkzaam zijn. Zij zullen deze kennis echter alleen willen overdragen indien er een garantie is dat ze zelf naderhand niet worden ontslagen. Die garantie is aanwezig als de werknemers het perspectief wordt geboden om binnen de organisatie te kunnen doorgroeien. Er ontstaat een hiërarchische functiestructuur waarbij nieuwe werknemers onderaan in de organisatie binnenkomen, waarna ze langs een functietraject of baanladder promotie kunnen maken. Binnen de interne arbeidsmarkt wordt het verloop dus beperkt en kan de beloningsstructuur gekoppeld worden aan de functies in plaats van aan de werknemers (vgl. Williamson, 1975).

Glebbeek (1993) combineert de theorie van de interne arbeidsmarkten met de efficiency wage theorie om te komen tot een gereconstrueerde segmenteringstheorie, waarin de rantsoenering van primaire banen en de arbeidsmarktendogene kwalificering centraal staan. De rantsoenering van de aantrekkelijke arbeidsplaatsen in het primaire segment ontstaat doordat er lonen worden betaald die boven de marktprijs liggen. Dit leidt tot endogene, in het arbeidsproces zelf besloten liggende verschillen in mobiliteitsmogelijkheden en dito patronen (Glebbeek, 1993 p. 32). Verdere kwalificering wordt mede een functie van de arbeidsplaats, waardoor de werknemer beperkt wordt in de demonstreerbaarheid van zijn produktieve eigenschappen. De werkgevers bepalen via 'stratified investments' (Rosenbaum, 1989) welke werknemers in aanmerking komen voor verdere (bedrijfsgerichte) opleidingen en vervolgfuncties. Het zijn dus juist de werkgevers die bepalen welke mogelijkheden de werknemers krijgen om zich verder te kwalificeren en door te stromen naar vervolgfuncties. 
De mogelijkheden op de interne markt voor sequentiële opeenvolging van te doorlopen functies zijn doorgaans bekend bij de werknemers en de bijbehorende promotiemogelijkheden werken motiverend, waardoor er minder direkte vormen van controle nodig zijn (Van der Meer, 1993). Werknemers zullen zich ook eerder voegen in de bedrijfscultuur. Immers wie uit de pas loopt, loopt ook de promotie mis. Tenslotte kunnen de werknemers tijdens hun carrière op relatief eenvoudige en goedkope wijze worden gevolgd, waarmee de onzekerheid over de produktieve vaardigheden van de werknemer bij intrede in de organisatie kan worden weggenomen.

De toegang tot het primaire segment wordt reeds vóór de arbeidsmarktintrede bepaald op basis van opleiding en sociale stratificatie. Omdat er weinig mobiliteit is tussen het primaire en het secundaire segment zijn de verschillen in arbeidsmarktpositie structureel. Na de selectie voor de intrede in de zogenaamde 'entry ports' van de interne arbeidsmarkt, heeft men via functie- ladders de mogelijkheid om verder binnen de organisatie door te groeien. Toch stopt het selectieproces niet na de intrede. Om de top van een functietraject te bereiken zijn immers meerdere promotieronden voorzien waarvoor men zich moet kwalificeren.

Rosenbaum (1984) onderscheidt drie verschillende promotieregimes die zich kunnen voordoen. In de 'contest mobility' wordt de selectie van de werknemers voor verdere doorgroei zo lang mogelijk uitgesteld. Dit is enerzijds motiverend, omdat de werknemer langer het vooruitzicht heeft op promotie (opportunity). Anderzijds is ook niemand zijn of haar positie zeker. Deze wijze van selectie zal zich voordoen in een open arbeidsmarkt, waarbij een hoge mate van competitie tussen de medewerkers is toegestaan. Sonnenfeld (1989) typeert deze situatie ook wel als een Baseball Team.

Het andere uiterste, de 'sponsored mobility' benadrukt de efficiency van de bedrijfsvoering. De besluitvorming omtrent promoties vindt reeds aan het begin van de carrière plaats en is definitief. Situaties waarin deze 'sponsored mobility' optreedt zijn beroepen(trajecten) die extreem hoge kosten met zich mee brengen (jachtvliegers, artsen), of als een beroepsgroep er in slaagt om de vakdeelmarkt af te bakenen met behulp van het stellen van opleidingseisen en wetgeving. In deze credentialistische visie is de noodzaak voor competitie niet aanwezig. ledereen heeft immers al een carrière en concurrenten worden met behulp van regels buiten de beroepsgroep gehouden. In Nederland geldt dit met name voor het notariaat en de advocatuur.

Het 'tournament mobility' model tenslotte is een middenweg tussen de eerder genoemde twee uitersten. Competitie voor promotie (motivatie) en selectie (vanwege efficiency) worden in deze variant gecombineerd. Tijdens de loopbaan zijn er meerdere promotiekansen, maar alleen degenen die blijven winnen gaan door voor de hoogste plaatsen in de hiërarchie. Degenen die in een promotieronde moeten afhaken kunnen verdere promoties vergeten (en gaan alleen nog door voor de troostprijzen). Met name op een interne arbeidsmarkt is deze toernooivariant te verwachten. Gaandeweg de carrière krijgt de werkgever immers steeds meer zicht op de ware kwaliteiten van de werknemer. Bovendien wordt de groep kandidaten tijdens de weg naar het hoogste traject steeds kleiner, zodat de monitoring van de kandidaten beheersbaar blijt.

In feite zijn deze mobiliteitsregimes matching processen waarmee werknemers aan functies worden gekoppeld (Rosenbaum, 1989). Vanuit de organisatie moet de keuze gemaakt worden wie, wanneer, welke promotie kan maken en daarvoor additionele scholing kan, of moet gaan volgen. Zowel vanuit de beheersbaarheid van de monitoring van de werknemers, als vanuit de (opleidings-)kosten die verbonden zijn aan het voorbereiden op een volgende stap op de carrièreladder wordt steeds een afweging gemaakt tussen opportunity en efficiency. 


\section{Conclusie}

In dit paper hebben we de relatie tussen scholing en carrière besproken vanuit de economische arbeidsmarkttheorieën. Op voorhand was duidelijk dat dit de moeilijk zou zijn (Hachen, 1990), omdat in de meeste theorieën de nadruk ligt op het beschrijven van de allocatie en de beloning van arbeid en nauwelijks wordt ingegaan op de relatie tussen scholing en carrière. Toch kunnen we over deze relatie een aantal conclusies trekken

Opleiding speelt een belangrijke rol bij de intrede op de arbeidmarkt, die varieert van het toekennen van produktieve vaardigheden in de human capital theorie, tot opleiding als een signaleringsinstrument of indicator voor trainingskosten.

Volgens de segmenteringstheorieën neemt de invloed van scholing in de latere loopbaan echter af, omdat op de interne arbeidsmarkt de signaleringsfunctie wordt overgenomen door de directe monitoring van de werknemers in de diverse functieketens.

Op de vakdeelmarkten echter blijft opleiding de standaard bij het tot stand komen van transacties op de arbeidsmarkt. Geheel in lijn met de transactiekostentheorie van Williamson ontstaat er nu geen organisatie, maar een markt waarop de arbeid verhandeld wordt. De mobiliteit van de werknemers op deze vakdeelmarkten wordt juist mogelijk gemaakt omdat de gevolgde opleiding als een standaard fungeert voor de beschikbare kennis en vaardigheden.

Op de secundaire arbeidsmarkt komen de transacties eveneens via de markt tot stand. Opleiding speelt nu echter een minder essentiële rol, vooral omdat het functies betreft die weinig scholing behoeven. Het betreft de markt met de slechte banen zonder carrièreperspectieven. Zoeken naar een verband tussen scholing en carrière wordt dan erg moeilijk.

Uit zowel de neoklassieke, als de institutionele arbeidsmarkttheorieën komt echter steeds naar voren dat arbeid, juist vanwege die scholingsaspecten, een vaste kostencomponent heeft. De verworven bedrijfsspecifieke kennis en vaardigheden maken het voor zowel de werknemer als de werkgever aantrekkelijk om langdurige arbeidsrelaties aan te gaan, waardoor er een rem op de externe mobiliteit ontstaat.

Scholing stopt niet bij de arbeidsmarktintrede. Naast training on-the-job is (bedrijfs)scholing een belangrijk middel voor het aanleren van specifieke vaardigheden, die vaak nodig zijn om te kunnen doorstromen naar een volgende functie. In welke mate scholing, inclusief de scholing na intrede op de arbeidsmarkt, van invloed is op het te volgen carrièretraject is echter nog onduidelijk. Glebbeek (1993) geeft aan dat er een impliciete relatie is tussen scholing en carrière via arbeidsmarktendogene kwalificering. Hierdoor komen alleen degenen die carrière maken in aanmerking voor additionele scholing, die weer nodig is voor de verdere loopbaanontwikkeling.

Een goede start op de arbeidsmarkt is belangrijk, omdat de eerste baan waarin men terecht komt vaak de aanzet is voor de verdere carrière. Het is daarom van belang om meer inzicht te krijgen in de relatie tussen scholing en carrière. Niet alleen voor wat betreft de arbeidsmarktintrede, maar ook voor de implicaties later in de arbeidsloopbaan. Vanuit het standpunt van de studie- en beroepskeuze is het daarom belangrijk dat er goede informatie aanwezig is over de aansluiting tussen het onderwijs en de arbeidsmarkt en de rol van de opleiding (en eerder carrièretraject) in de verdere loopbaan. 


\section{Literatuur}

Allmendinger, J. (1989), Educational systems and labor market outcomes, European Sociological Review, Vol. 5 No. 3 (December), 231-250.

Althauser, R.P., A.L. Kalleberg (1981), Firms, Occupations, and the Structure of Labor Markets: A Conceptual Analysis, in: Sociological Perspectives on Labor Markets, pp 119-149, Academic Press.

Arthur M.B., D.T. Hall, B.S. Lawrence (1989), Generating new directions in career theory: the case for a trandisciplinary approach, in: Handbook of Career Theory, edited by M.B. Arthur, D.T. Hall and B.S. Lawrence, Cambridge University Press.

Becker, G.S. (1983), Human Capital, a Theoretical and Empirical Analysis, with Special Reference to Education, second edition, The University of Chicago Press, Midway Reprint.

Bielby, W.T. (1981), Models of Status Attainment, Research in Social Stratification and Mobility, Vol. 1, 3-26.

Blossfeld, H-P (1986), Career opportunities in the Federal Republic of Germany: a dynamic approach to the study of lifecourse, cohort, and period effects, European Sociological Review, Vol. 2 No. 3 (December), 208-225.

Cairnes, J.E. (1873), Some Leading Principles of Political Economy Newly Expounded, MacMillan, London.

Centraal Bestuur voor de Arbeidsvoorziening (1993), Schoolverlatersbrief 1993, Den Haag.

Doeringer, P.B., M.J. Piore (1971), Internal labor markets and manpower analysis, Heath, Lexington.

Glebbeek, A.C. (1993), Perspectieven op loopbanen, proefschrift, Groningen.

Gowler. D. and K. Legge (1989), Rhetoric in bureaucratic careers: managing the meaning of management succes, in: Handbook of Career Theory, edited by M.B. Arthur, D.T. Hall and B.S. Lawrence, Cambridge University Press, p 437-453.

Grip, A. de (1985), Interne arbeidsmarkttheorieën: een overzicht, Maandschrift Economie, Jaargang 49 No. 4, 333-345.

Grip, A. de (1987), Onderwijs en arbeidsmarkt: scholingsdiscrepanties, proefschrift, Amsterdam.

Hachen Jr., D.S. (1990), Three Models of Job Mobility in Labor Markets, Work and Occupations, Vol. 17 No. 3 , August 1990, 320-354.

Hondeghem, A. (1990), De loopbaan van de ambtenaar. Tussen droom en werkelijkheid, proefschrift, Amsterdam.

Hoof, J.J. van, J. Dronkers (1980), Onderwijs en arbeidsmarkt: een verkenning van de relaties tussen onderwijs, arbeidsmarkt en arbeidssysteem, Sociologische Monografieën, Van Loghum Slaterus, Deventer.

Kerr, C. (1954), The Balkanization of Labour Markets, in: Labor Mobility and Economic Opportunity, edited by E.W. Bakke, MIT, Cambridge.

Lutz, B., W. Sengenberger (1974), Arbeitsmarktstruktur und öffentliche Arbeidsmarktpolitik, eine Kritische Analyse von Zielen und Instrumenten, Göttingen.

Mayer, K.U., G.R. Carrol (1987), Jobs and classes: structural constraints on career mobility, European Sociological Review, Vol. 8 No. 1 (May), pp 14-38.

McNabb, R. (1987), Labour Market Theories and Education, in: Economics of Education: Research and Studies, edited by G. Psacharopoulos, Pergamon Press, pp. 157-163.

Meer, P. van der (1993), Verdringing op de Nederlandse arbeidsmarkt, sector- en sekseverschillen, proefschrift, Amsterdam.

Mintzberg, H. (1983), Structure in fives: designing effective organizations, Prentice-Hall International.

Ohlsson, R., A. Nilsson (1984), The Labour Market and Structural Changes in the Economy-Higher Education us a Storage Device?, Mimeo, Department of Economic History, University of Lund, Sweden.

Olzewski, D.E. (1981), Career paths and vocational education, in: Jobs and training in the 1980's. Vacational policy and the labor market, edited by P.B. Doeringer and B. Vermeulen, Martinus Nijhoff Publishing, Boston.

Ophem, H. van (1989), Theoretical and empirical studies on job mobility, University of Amsterdam.

Pfriem, H. (1979), Konkurrierende Arbeitsmarkttheorien. Neoklassische, duale und radikale Ansätze, Campus Verlag, Frankfurt.

Prendergast, C. (1993), The Role of Promotion in Inducing Specific Human Capital Acquisition, The Quarterly Journal of Economics, pp. 523-534.

Rosenbaum, J.E. (1984), Career Mobility in a Corporate Hierarchy, Academic Press, Orlando.

Rosenbaum, J.E. (1989), Organization career systems and employee misperceptions, in: Handbook of Career Theory, edited by M.B. Arthur, D.T. Hall and B.S. Lawrence, Cambridge University Press, Chapter 16 pp 329-353.

Sicherman, N. (1990), Education and occupational mobility, Economics of Education Review, Vol. 9 No. 2, 163-179.

Sonnenfeld, J.A. (1989), Career System Profiles and Strategic Staffing, in: Handbook of Career Theory, edited by M.B. Arthur, D.T. Hall and B.S. Lawrence, Cambridge University Press.

Spence,A.M. (1974), Market Signaling: Informational Transfer in Hiring and Related Training Processes, Cambridge MA, Harvard. 
Spilerman, S. (1977), Careers, Labor Market Structure, and Socioeconomic Achievement, American Journal of Sociology Vol. 83 No. 3, 551-593.

Stiglitz, J.E. (1975), Lucentives, Risk and Information: Notes towards a Theory of Hierarchy, The Bell Journal of Economics, 6 , pp. $552-579$.

Taubman, P., M.L. Wachter (1986), Segmented Labor Markets, Chapter 21 in: Handbook of Labor Economics, Vol. 2 , edited by O. Ashenfelter and R. Layard, pp. 1183-1217, North Holland, Amsterdam.

Thurow, L.C. (1975), Gerierating Inequality, Mechanisms of Distribution the U.S. Economy, Basic Books, New York.

Topel, R.H., M.P. Ward (1988), Job mobility and the careers of young men, Working paper N.B.E.R., No. 2649, Cambridge (MA).

Williamson, O.E. (1975), Markets and Hierarchies: Analysis and Antitrust Implications, The Free Press, New York.

Wolfs, G.L.M. (1990), Tenure in the Dutch Economy, Researchmemorandum Rijksuniversiteit Limburg, No. 90-042, Maastricht. 